\title{
1970-2020: A fifty year history the personal social services and social work in England and across the United Kingdom
}

\author{
Ray Jones ${ }^{1}$
}

\begin{abstract}
: 2020 is the fiftieth anniversary of the creation of a unified profession of social work across the United Kingdom and of the creation of integrated personal social services in each of the four UK countries. This paper reflects on the genesis of these changes, tracks developments over the past fifty years, and comments on the current state of social work and the personal social services in England and throughout the UK.
\end{abstract}

Keywords: social work; personal social services; history; England; United Kingdom

1. Emeritus Professor of Social Work, Kingston University, UK

Address for correspondence: ray.jonesl@hotmail.co.uk

Date of first (online) publication: 15th July 2020 
The 1960s were a time when social science, especially sociology, had a particular place and profile in influencing policy and practice within social work and the social services - and also in, for example, schools and education. It was a reshaping and repositioning from the focus on social psychology and the psychodynamic emphasis of the 1950s, characterised for example by the attention given to John Bowlby's concept of the impact of maternal deprivation (Bowlby, 1953) and to the American imports of models of individual and therapeutically oriented social casework (see, for example, Hamilton, 1957; Perlman, 1957; Hollis, 1964), and is certainly a contrast with the priority given to economics in the 1980s and indeed today. The space taken today by the Institute for Economic Affairs and the Institute for Fiscal Studies (formed respectively in the 1950s and 1960s but with relatively little profile at the time) contrasts in the 1960s with the influence of the Institute for Community Studies (Young and Wilmott, 1957; Wilmott and Young, 1960; Wilmott, 1966) and the Institute for Criminology (see, for example, West and Farrington, 1973).

The 1960s were also, and this was not unrelated to the prevalence of the sociological analysis of community, power and inequality, a time of growth in pressure groups targeting social issues such as poverty and disadvantage. It was a decade which saw the formation of the Child Poverty Action Group, Shelter, Gingerbread, and the Disablement Income Group.

The activists within these organisations were often shapers and recipients of the expanding social science, and especially sociology, courses within universities, and in particular the new universities established in the 1960s, such as Essex, Sussex and East Anglia, and those that had their routes in former Colleges of Advanced Technology such as Bath and Brunel. These latter new universities, along with Keele, Lancaster, and Bradford, and the new polytechnics, such as East London and North London, integrated within four year degrees the study of the social sciences, and again especially sociology, with a qualifying education and training in social work.

This was a move on from the social administration and psychodynamic casework focussed social work education which had been provided at the longer-standing universities of, for example, Birmingham, the London School of Economics and Glasgow and Edinburgh and expanded social work into the fields of group work and community work.

The new universities and polytechnics also expanded the availability and opportunities of higher education to an increasing proportion of young people, including more children from families in lower socio-economic groups, and with a focus on applied knowledge the courses were more related to preparation for future employment and careers. These were two factors which made social work degrees provided within a discipline of sociology and department of social sceinces attractive for potential students.

The four year Bath University Batchelor of Science degree established in 1966, for example, included modules on sociological theory, the sociology of industrial societies, the sociology of social problems, the sociology of organisations, the 
sociology of education, criminology, social research methods, social psychology, social philosophy, and economics, as well as modules on social work skills, social services legislation, social administration and the welfare state, human growth and development, and welfare rights. By the mid-1970s the university was teaching separate modules on casework, group work and community work before then bringing them together with what were termed integrated and unified methods.

It was within this mix and maelstrom of social science change in the 1960s that social work and the personal social services were re-shaped and were also to gain greater attention. It is now 50 years since the step changes of 1970 across the United Kingdom of creating a unified profession of social work and integrated personal social services.

\section{Setting the scene}

Not only is 2020 a significant fiftieth anniversary for social work and the personal social services in the United Kingdom. It is also a significant seventy fifth anniversary. It was seventy five years ago that a substantial state platform for social work and the personal services was established as a part of the post-Second World War foundation of the British welfare state. It was, however, a disjointed platform with the legislation of the mid and late 1940s both cementing a state commitment to what would come to be known as social work and the personal social services but also creating division and separation.

Social work in the UK and elsewhere, of course, has a history which pre-dates the 1940 welfare state reforms, especially within the charitable and philanthropic organisations developed in the nineteenth century, in mutual aid organisations and trade unions, in court welfare services, in hospital almoners, and in the changing role of Poor Law relieving officers.

But it was key legislation as a part of the welfare state reforms in the 1940s (Timmins, 1996) which largely structured the organisational base, and delineated the statutory responsibilities, for state-provided social work services. However, these were shaped and set within three different Acts and within several other Acts which also had a relationship and relevance for social work.

The three main Acts were the 1948 Children Act which created the role of children's officers to head local authority children's departments which employed child care officers (Holman 1998, 2001); the 1948 National Assistance Act which replaced the previous Poor Law legislation and led to creation of local authority welfare departments to assist and provide care for, primarily, older people and employing welfare officers, many of whom had been the relieving officers within the former Poor Law (Burnham, 2012), and the 1946 National Health Service Act which at the time gave local authorities public health responsibilities to be fulfilled by 
medical officers of health (some of whom also headed the welfare departments while others were led by chief welfare officers) but with treatment services in hospitals and community clinics to be provided within a national NHS and with general medical practitioners (GPs) as individual self-employed contractors who worked with the NHS (Rivett, 1998). Almoners, who would from the 1960s be retitled as medical social workers (Butrym, 1968; Baraclough et al, 1996), psychiatric social workers working within hospitals and clinics (Timms, 1964), and 'duly authorised officers' who were warranted under the then existing mental health legislation were employed by the NHS (following the 1959 Mental Health Act duly authorised officers became mental welfare officers and were employed by local authorities - see Rolph et al, 2003).

Separate again were probation officers. This role was established by the 1907 Probation of Offenders Act which gave magistrates courts the power to appoint probation officers to 'advise, assist and befriend' offenders, and replacing voluntary 'court missionaries'. Probation officers were to be formally employed by local authorities but in 1938 the Home Office took responsibility for probation officers, albeit probation services were to be delivered by local probation committees (Vanstone, 2004).

There was also the continuation of social work roles within voluntary charitable organisations, such as the 'moral welfare officers' employed within religious charities who worked with young mothers and, for example, arranged the adoption of children.

The fragmentation and separation of what were to become largely recognised as social work services is reflected in the complexity of the paragraphs above! The divisions in roles and employers was also reflected in the divisions of the education, training and qualifications for each of the separate occupational groups.

Each of the groups of separate and specialist workers had their own representative organisations in addition to possibly being members of a trade union. Since 1935 there had been a British Federation of Social Workers open to all social workers, which in 1951 became the Association of Social Workers, but social work was still fragmented across different occupational organisations with differing membership requirements - such as the Association of Child Care Officers, the Association of Psychiatric Social Workers, and the Institute of Medical Social Workers (Payne, 2002).

In 1963 eight of these organisations, whilst retaining their own identities and membership, formed the Standing Conference of Social Work Organisations with the initial intention of improving the influence of social workers through a coordinated voice and then through campaigning for one merged professional association for all social workers. In addition to the separate organisations for social workers there had also been separate education, training and qualifications, or none at all, for the different occupational groups.

But the move towards a generic education and training was already underway following a report, funded by the Carnegie Trust, by Dame Eileen Younghusband in 1947 (Younghusband, 1947)). She noted the wide range of roles and agencies 
in which social workers were employed and the commonality which underlay their work. A consequence was the establishment in 1954 of a generic course at the London School of Economics which was not without conflict and controversy from those who were convinced and committed to specialist social work courses (Donnison 1975; Oakley 2014), and with generic courses created at, for example, at the University of Birmingham in 1956 (Davies, 2008).

The promotion of generic education and training for social workers was further promoted by the recommendations of a government-commissioned working party on social work, chaired by Younghusband (Younghusband, 1959). It led to the creation in 1961 of a National Institute for Social Work Training (NISWT) and, following the 1962 Health Visiting and Social Work Training Act, to the founding of the Council for Training in Social Work, which was followed in the mid-1960s by the expansion of social work qualifying education at the new universities.

As well as qualifying with their social science degrees students were awarded a range of professional qualifications such as the Home Office Letter of Recognition in Child Care or membership of the Association of Psychiatric Social Workers, reflecting that social work was still a fragmented profession divided by separate specialist roles, different departments within local authorities as well as other employers, and a range of professional qualifications.

\section{The coming together in the late 1960s and 1970s}

Alongside the emerging ambitions and actions of the Standing Conference of Social Work Organisations throughout the 1960s to promote a unification of the profession of social work across the UK, there was a separate related push towards an integrated local authority home base for the personal social services within which social work would be the lead profession.

What drove this development across the UK was not the unification of social work but, in part, a concern about juvenile delinquency and youth crime, which was escalating as a consequence of the bulge in the population of adolescents who were born in the post-war baby boom years of the late 1940s and early 1950s.

It was Scotland that moved ahead most quickly with the setting up of the Kilbrandon Committee in 1961 which reported in 1964. It noted the similarities between children who were seen to have offended and those needing care and protection. It recommended that the children should not be dealt with by the criminal courts but by children's panels and by a new 'social education department' based within education authorities. However, there had already been the 1963 McBoyle Report on 'The Prevention of Neglect in Children' which proposed that a comprehensive family welfare service should be established.

Running alongside the debates and deliberations in Scotland about children was 
the coming together of different occupational groups of social workers who were identifying common methods of working and a shared identity (Cooper, 1983, p. 46). Vera Hiddleston, who was the director of the Scottish Probation Training programme, chaired the Scottish social workers' parliamentary group. She recalled

we lobbied the political parties in the House of Commons, and orchestrated the lobbying of constituency MPs. We prepared briefs for the government and opposition.

(Hiddleston, 2006)

It was the successful collective canvassing by social workers in Scotland which contributed to changing the proposal from 'social education departments' within education authorities into the reality of a social work-led family service. This was legislated for by the 1968 Social Work (Scotland) Act which brought together into integrated local authority social work departments children's, mental health, learning disability, physical impairment, older persons and probation services.

Three significant figures advised the Scottish Office and the Scottish Secretary of State. Kay Carmichael and Megan Browne were in the vanguard of social work education developments at Glasgow and Edinburgh universities. The third advisor was Richard Titmuss, Professor of Social Administration at the London School of Economics. Why is this significant? In 1965 he spoke at a Royal Society of Health Conference arguing that a 'Family Service Department is not broad enough' as 'we have to remember that large number of needs arising in the community are not essentially 'family needs'; mentally ill migrants, elderly widows and widowers, the isolates and childless, unmarried mothers and other categories of people who, in an increasingly mobile society might well hesitate before turning to a 'Family Department'. He also commented 'I am doubtful whether a Family Service Department would effectively bring together within one administrative structure all social workers in the employ of a single local authority' (Titmuss, 1965, p. 19). His solution was a 'Department of Social Service'. Not only was Titmuss advising in Scotland. He was also close to and advising the Labour government in England.

In England and Wales there were a sequence of working parties and White Papers throughout the 1960s which culminated in the 1969 Children and Young Persons Act. In the welfare-orientated spirit of the times it recognised that children who were sad, mad and bad were in essence the same children who had poor life and poor parenting experiences.

An argument was advanced for a family social service to assist families to care well for their children. The scope of this family service was being shaped at the same time that there was an increasing concern about the realities and impact of the experience of life within big institutions (Goffman, 1961; Townsend, 1962; Robb, 1967) with the commitment to move away from the large long-stay county asylums and mental handicap hospitals and geriatric wards and when there was an increasing aged population and younger disabled people were living for longer. The scope of a new family service, as argued by Titmuss, should be inclusive of all 
who might need help from social workers.

A prominent group of academics and social work practitioners who were closely connected with the then new Labour government came together in 1964. They prepared a memorandum for the government which asked for an enquiry into the integration of local authority social work services arguing that the current fragmented arrangements were wasteful, ineffective, and did not make the best use of the professional skills of social workers.

Among the members of this pressure group were Richard Titmuss from the London School of Economics, Robin Huws Jones, the Principal of the National Institute for Social Work Training, and David Jones, the chair of the Standing Conference of Organisations of Social Workers. Their canvassing led to the Seebohm Committee which was established in 1965 and reported in 1968. The LSE and NISWT were each to have members on the Seebohm Committee. It was a time of concerted action by a closely interlinked network of those who were committed to the promotion of social work as a profession and for this to be achieved through the bringing together of different professional interests into one service (Hall, 1976).

The Committee's recommendations included merging the tri-partite local authority children's, welfare and mental health services into new social services departments, for all social workers to have the same initial education and training to be overseen by one central council for social work education, with one professional qualification. The committee canvassed for a local authority department which included residential, day care and home help services and with area teams of social workers serving populations of 50,000 to 100,000 people and where the social workers and others in the teams would work with people across the age range and across a range of needs previously covered before by the three separate local authority services. These teams would be managed within a department "where the objective should be that most heads of the social services departments are professionally qualified in social work' (Seebohm Committee, 1968, p. 190). It was argued that this large local authority department would be well placed to fight for a larger share of resources and also be more easily accessed by those needing help.

In addition to work with individuals and families the Seebohm Committee argued for 'a wider conception of social service, directed to the well-being of the whole community and not only to social casualties, and seeing the community it serves as the basis of its authority, resources and effectiveness' (Seebohm Report, 19687, p. 147). The Committee also canvassed for a research capacity, including within local authorities, to plan, evaluate and develop the personal social services, and for post-qualifying education and training for social workers which would enable the development of specialist workers who could be called upon when necessary and appropriate by the generic frontline workers. With its focus on community as well as individuals, and with its advocacy for research, the committee reflected the social, and social science, orientation of its members.

But even in the heady days for social work in the energised and effervescent late 
1960s, with a Labour government committed to further public service development and with the welfare state still receiving cross-party and public support, it was not axiomatic or automatic that the Seebohm proposals would be accepted and enacted. There were competing potential ways forward, such as bringing the personal social services into the NHS and conflicting interests, such as those of local authority medical officers of health, who did not see a personal social services department with social work as the lead profession as the desirable way forward.

The government also already had a busy agenda with NHS, education, employment, trade union, and more general local government reform underway. Within this broader context local authority social work services were potentially a minor and marginal concern.

As in Scotland, it was the motivation and mobilisation of those working within what were to become local authority social services in England and Wales which kept the Seebohm vision and recommendations alive and moving forward. In addition to the members of the Committee pushing for action a Seebohm Implication Action Group (SIAG) was formed, chaired by Tom White with Keith Bilton as it secretary. Both also had keys roles in the Association of Child Care Officers. Judith Niechcial in her biography of Lucy Faithful, who was at the time the Children's Officer for Oxfordshire, noted that

Tom White developed a sophisticated campaign. He obtained funding from the National Institute for Social Work, SIAG members visited their MPs in their constituency surgeries to ensure they were properly briefed, and there was a mass lobby of Parliament by social workers. Notes were produced for public speakers ... Such lobbying was uncommon in those days. (Niechcial, 2010, p.90)

As in Scotland, in England and Wales it was the concerted and collective action of social workers which led to the change they were seeking, mirroring the growth of pressure group activity and actions at the time. There was, however, a difference. Both the Kilbrandon and Seebohm committees recommended the creation of family social services to bring together in one local authority department the three separate children's, welfare and mental health departments. In Scotland it was also to include the probation service but in England and Wales probation officers resisted becoming part of an integrated local authority personal social service. They successfully argued that they should remain accountable to the Home Office as the central government department responsible for the courts and tackling crime. Probation officers also retained their separate professional association, although probation officers as social workers - which is how they were educated and qualified - could also join the new unified social work professional association which was about to be created.

The decision in England and Wales for probation to stay outside of the arrangements being made to create local authority personal social services was to have consequences for probation officers in 1997 when the government decided that they would no longer be social work trained and they were to become part of 
a National Offenders Management Service, along with prisons. Their 'advise, assist and befriend' role was replaced by their becoming monitoring and supervising officers within a penal and correctional service (Bamford, 2020). Probation officers were further distanced from social workers in 2013 when the government took the disastrous decision (Doward, 2019) that two thirds of the probation service in England and Wales was to be privatised into Community Rehabilitation Companies, creating an opportunity for the big out-sourcing companies such as SERCO to move in to the probation marketplace which was created.

In Northern Ireland in the early 1970s integration for the personal social services and social work took a different direction. It was the most intense time in the invidious and insidious impact of the 'troubles' with sectarianism, civil disorder and indiscriminate violence at a peak, and local councils were seen to be immersed in sectarianism and religious and political discrimination (Pinkerton and Campbell, 2002; Campbell, 2007).

It was in this context that the governing of Northern Ireland moved from Belfast and Stormont to Westminster and Whitehall. Social services were placed within four Health and Social Services Boards and with social work managers headed by a director of social services who was a senior member of the Health and Social Services Board. This was to change in 1991 when unit general management was introduced and the social workers could be and were managed by other professions (as well as social workers managing other professions) and directors of social services became professional advisors within the Boards rather than senior social services manager (Bamford, 1993). Pinkerton and Campbell commented:

Although the early part of the Troubles were characterized by the intense violence which traumatized many individuals, families and communities, for social work the period marked a coming of age, as the occupation expanded in numbers, gained more access to resources and enhanced its professional authority within the new board structures. The occupation moved from its relatively minor and very traditional welfare function in local government and hospitals, to being a key young profession within the new state bureaucracies. (Pinkerton and Campbell, 2002, p. 729)

\section{Themes and topics and twists and turns}

There was a similar 'coming of age' for social workers in England and Wales and in Scotland. In 1968 the Social Work (Scotland) Act created local authority social work departments in Scotland. In 1970 the Local Authority Social Services Act created local authority social services departments in England and Wales. In the same year the British Association of Social Workers was formed by bringing together seven of the eight social work associations (minus the National Association of Probation Officers).

The new large local authority social services and social work departments, 
led by directors of social services and directors of social work, were now a major local government responsibility. They directly employed more people than other departments (with schools semi-independent of Education Departments with their own governors and head teachers), had significant revenue budgets, and were increasingly of interest to the media.

What has happened in the fifty years since 1970? The twist and turns and major themes within key topics are discussed below.

\section{Professionalisation}

From the beginning of the British Association of Social Workers in 1970 there was disagreement and discord. The development and challenges of professionalization within social work and other public services in the United Kingdom has been well tracked and analysed by Malin (2020), and Frost (2005) has noted the particular tensions for workers with discrete professional identities and orientations working in multi-professional teams and services.

For social workers in the early 1970s there were those who held to a Durkheimian view of professionals as essentially disinterested experts whose aim was to serve others while some had a more Weberian concern that professions were, in essence, self-protecting and self-promoting. Others held the view of Etzioni (1969) that social work was likely to be no more than a semi-profession as it did not have a distinct and developed ownership of a knowledge base.

The dispute within the British Association of Social Workers centred on two issues. First, who were to be allowed to be members of a unified UK-wide professional association of social workers. Secondly, should social workers even want social work to be recognised and accepted as a profession.

The intention was that qualified and unqualified members of the existing social work associations should be able to become members of the newly formed British Association of Social Workers but that future new members would have to hold a recognised professional qualification in social work. Unqualified social workers could be associate, but not full, members of BASW. However, as noted by Bilton,

The pressure from members for equality of membership rights for both qualified and unqualified practitioners arose unexpectedly quickly ... Within a short period BASW was seen by many of its members much less as an association of people working in a variety of employment settings but sharing a common qualification and much more as an organisation representing those who worked in Social Services and Social Work

Departments. (Bilton, 2008)

This hints at another issue for the newly-fledged BASW as "leaders sought to maintain a united stance, involving an uneasy balance between community rights 
firebrands on the one hand and staid family caseworkers on the other' (Ivory, 2010).

In particular, it raised the issue of whether BASW should be a professional association (with restricted membership) or a trade union negotiating salaries and terms and conditions of employment for all social workers (Payne, 2010). This was in part resolved in 1978 when BASW supported the formation of the British Union of Social Workers, although social workers were more likely to be members of the local government trade union NALGO which also opened it membership to social workers working within voluntary organisations.

It was not until 2002, however, that social work across the UK achieved the characteristics associated with a fully-fledged profession when the 2000 Care Standards Act was implemented. It made 'social worker' a protected title which could only be used by someone registered as a social worker with the registration bodies which were separately established in each UK nation. To be registered as a social worker it was necessary to hold a recognised professional qualification in social work which for the future was to be a graduate-level qualification. De-registration would result if the registering body deemed that the registrant did not meet the required standards of competence and behaviour or if they had not presented acceptable evidence of continuing professional learning and development.

This accreditation of social workers across the UK followed campaigning reaching back to 1975 when at the BASW annual meeting a motion was passed calling for the accreditation of social workers based on qualification and competence (Bamford, 2015; Jones, 2018). Accreditation was considered in the early 1980s by the Barclay Committee but the Committee decided there was not enough support or agreement to recommend accreditation of social workers and the time was not right or ripe in the context of a Conservative government which was hardly supportive or sympathetic towards social workers (Barclay Report, 1982). With the support of the National Institute for Social Work the impetus was picked up again in 1990 with a 'Safeguarding Standards' report prepared by Roy Parker (Parker, 1990) and with NISW publishing a consultation paper calling for a 'General Social Services Council' to register and regulate social workers (General Social Services Action Group, 1992).

There was an echo of the collective canvassing and campaigning to secure action following the Kilbrandon and Seebohm reports with an action group formed in the early 1990s to promote the accreditation of social workers. As in the 1960s, it was Labour, this time in opposition, which accepted accreditation as a policy commitment which was then followed through when Tony Blair's New Labour formed the government in the late 1990s (Secretary of State for Health, 1998).

Although there was ultimately success in campaigning for the accreditation of social workers, BASW as the professional association for UK social workers has not attracted the support and membership of the majority of those who were qualified as social workers or who were employed in social work roles. BASW hovered around 10,000 members throughout the 1970s and beyond, only expanding in the 2000s and 2010s to a membership of about 20,000, partly because of the professional 
indemnity and insurance policies it had negotiated and which were valued by the increasing numbers of independent and agency social workers.

To give this some context, in 2018 96,497 social workers were registered in England alone (Cromarty 2018). Data from a range of sources for the other UK nations show 5,965 social workers registered in Wales (Social Care Wales, 2017), 10,965 in Scotland (Scottish Government, 2016), and 6,169 in Northern Ireland (Northern Ireland Social Care Council, 2019). In Northern Ireland $(35,599)$ (Northern Ireland Social Care Council, 2019), Wales (9217) (Social Care Wales, 2019) and Scotland $(97,318)$ (Scottish Social Care Council, 2018) social care workers were also registered. In terms of scale and capacity extending registration to the much larger social care workforce beyond social workers was seen as step too far in England.

Overall, therefore, across the UK there are almost 120,000 social workers and BASW has only about one sixth of the eligible social workers as members. It also ought to be noted that social workers are only a minority of all the workers employed in statutory and non-statutory social services.

\section{Ideology and practice}

One of the reasons for the low take-up of BASW membership when BASW was formed was the concern about whether social work should aspire to be a profession. One argument was that this promoted good social work practice and protected the public (Butrym, 1976). The contrary position as argued by Simpkin, was that professionalization was elitist, self-protecting, self-promoting, and distanced social workers from those they were seeking to help (Simpkin, 1979; Rogowski, 2010).

Mike Simpkin was a member of the Editorial Collective of Case Con, a radical magazine for social workers (Weinstein, 2011). Radical social work, informed by a Marxist analysis of power and class (Corrigan and Leonard, 1978), was attractive to many of the entrants to social work who had studied sociology and other social sciences at, in particular, the new 1960s universities and polytechnics (Department for Education and Science, 1966). Indeed the introduction of four year combined sociology and social work degrees grounded the education of social workers in the social sciences.

This was at a time when, for example, the anti-psychiatry movement emphasised that disturbing and confusing relationships, especially within families, led to behaviours defined as mental disturbance within a medical model of illness (Cooper, 1967; Szasz, 1974). With its roots in American criminology, the new deviance theorists argued that deviancy was a social construct and that labelling someone as deviant was likely to lead to deviance amplification and membership of what were defined as deviant subcultures (Rock, 1973; Taylor et al, 1973). Howard Becker (Becker, 1967) asked 'Who Side are We On'. The answer for the young newly qualifying social workers was clear. They were on the side of those who were 
marginalised and minimalised by those who held power to stigmatise and stereotype poor people and those who challenged the status quo and expected behaviours.

Radical social work was seen as a means of being beside people who were harmed and hindered by deprivation and discrimination (Bailey and Brake, 1975; Brake and Bailey, 1980). It included 'consciousness raising', helping people not to accept the labels that they were inadequate or accepting that they were failures and were part of an 'underclass' but as people with common interests who through individual and collective action could and should respond and react to the social and economic forces which impinged on and penalised them.

This was a time when, albeit on a continuum of radicalisation, community action and community development were seen as integral to social work and were taught within a social work methods trilogy of casework, group work and community work. There then was the introduction of over-riding 'integrated methods' (Specht and Vickery, 1977) and 'unitary models' (Goldstein, 1973) conceptualising social work which sought to span the teaching of the methods trilogy.

Not only was radical social work about 'radicalising' social workers in their contact and work with those they were seeking to help. It also led to challenging within their employing agencies. The new embryonic large and bureaucratic social services departments were described as 'Seebohm factories', and as with industrial relations more generally throughout the 1970s these 'factories' were the source of, and venue for, conflict which resulted in strikes in 1979 by social workers and other employees in the social services departments. (McLaughlin, 2008, p. 28; Bamford, 2015 , p. 30). The support for strike action was greater in some (urban) areas that in other areas, but it reflected the strength of trade union membership at that time.

It was also a time when social workers were becoming more aware of, and active within, wider social movements to confront discrimination with the shaping of commitments to anti-discriminatory and anti-oppressive practice, and with challenges to restrictive, limiting and discriminatory definitions of gender, racial, cultural and sexual roles, orientation and status (Statham, 1978; Wilson, 1980; Dominelli, 1996; see also Dominelli, 1997; Dominelli and McLeod, 1998).

The 1970s were a time when the strategic and tactical were as important topics for social workers as the technical. The promotion and debates about radical social work were at the forefront of encouraging reflection within social work about its role, about the contribution it could and should make, and about the tensions as well as opportunities of its positioning within the UK as largely a service defined by statute and mainly although not exclusively provided within local authorities.

Was social work about social control or social change (Day, 1981)? Was social work about the personal or the political or both and if so how should these be integrated (Halmos, 1978; Pritchard and Taylor, 1978)? These were discussions and debates which were somewhat stifled and silenced under the seventeen years of Conservative governments from 1979 until 1997. 


\section{Organisation}

In 1979 the incoming Conservative government led by Margaret Thatcher, and following the social work strike, initiated a review of social work in England and Wales but with implications which were potentially UK-wide. It was to be administered by the National Institute for Social Work and chaired by Peter Barclay.

The Barclay Committee (Barclay Report, 1982) concluded with the view that social work had two roles which it described as counselling (with the focus on assisting individuals and networks of close relationships) and social planning (with attention to be paid to recognising, creating and harnessing community networks and resources) and with the case made for 'community social work':

Community social work is concerned both with responding to the existing social care needs of individuals and families and with reducing the number of such problems which arise in the future ... [It] demands that people who form a client's environment are seen for what they are or may be - an essential component of the client's welfare (Barclay Report, 1982, p. 205).

The contestability about social work's role and remit were reflected, however, in two minority reports by members of the Barclay Committee. The first argued that social work should have more limited horizons, be defined by the remit of the agencies in which it is located, and focused on social casework (Pinker, 1982). The second minority report argued that social work should be embedded in neighbourhoods of about 10,000 people with resources more devolved and decentralised (Hadley, 1982; 1987).

The two minority reports potentially took social work and its organisation in diametrically opposite directions. The first was a model of specialist workers fulfilling their agencies' remit and providing a targeted and selective service (Pinker, 1982). The second was a pitch for more generic workers located in patch teams located within small neighbourhoods providing a more universal service in partnership with the community (Hadley, 1982, 1987).

\section{Generic or specialist}

The generic-specialist worker and team debate was high profile during the 1970s and in to the 1980s (Parsloe, 1981; Stevenson1981). The Seebohm Committee's recommendation of generic social workers located in social services area teams but backed up by more specialist social workers who could be called upon when necessary did not get fully followed through as the focus on building the area teams held the attention and a second tier of specialist workers did not materialise.

There was still, however, often a degree of specialisation either through a weighting 
of different types of work for different social workers and with some retaining a fully specialist workload based on their previous experience. Over time, however, genericism came to dominate within area teams which, with variation between local authorities, also included occupational therapists, social work assistants, family aides, home care organisers and home carers, nursery and childminding registration officers, community development workers, and administrative staff. The team leaders and managers were, however, almost invariably social workers.

Local authorities tended to have separate line management functional divisions for fieldwork, residential and day care services, research, development, planning and training, and possibly for administration (Rowbottom et al, 1974). These were functional divisions rather than divisions based on the previous pre-1970 service user groups

The 1980s, however, saw the emergence of specialism which was prompted by the development of joint teams with health services, especially as a part of the closure of the large long-stay hospitals and the development of community provision. Multi-professional and multi-agency community mental health teams (CMHTs) and community teams for people with a learning disability (CTPLDs) meant that local authority social workers based in these teams became mental health or learning disability specialists and the remaining social workers in the area social services teams no longer had workloads which included mental health and learning disability.

In the 1990s, as discussed below, social work specialisation within social services departments took a giant leap forward, or, possibly, backwards, as it began to replicate the pre-1970s divide between different service users. The generic-specialist debate has largely settled at this time in favour of specialisation. Indeed, specialisation has been taken much further than client groups to include differentiation in terms of task and service users' place within the continuum of their contact with social workers. It is now being reinforced by government-generated separate education and training and accreditation for children's social workers and adult social workers.

But specialist and separate services not only had implications for the breadth and balance of the workload of social workers. Generic social services area teams focussed on, and perhaps located within, communities of 30,000 to 50,000 people started to be replaced by more specialist teams serving larger populations and with centralisation replacing localisation. This also reflected a move away from a community focus and orientation to a technical and task focus, in part generated by more directives and demands from central government.

\section{Managerialism and the audit culture}

More guidance and requirements from central government, along with the inspection of social services, intensified during the 1980s and 1990s. It took personal social 
services agencies to a new level of rule-governed and rule-bound bureaucracy within a mechanistic and structural, rather than an organic and systems model, of organisations. It gave little attention or acknowledgement either to the need for social workers and others to have scope for some personal control and selfactualisation within their work (Maslow, 1954; Herzberg, 1968) or to the reality that as 'street-level bureaucrats' much of their practice and work was unseen and unknown (Lipsky, 1980).

It fed and fuelled increasing managerialism within the personal social services as a part of a more general thrust to what was called New Public Management (Ferlie et al, 1996; Clarke and Newman, 1997). It was to lead to more focus on money, budgeting and bottom-line expenditure, with accountants as the profession with primacy, and more monitoring of how social workers and others spent their time, with targets, timescales and tick-boxes as means of regulating and recording workflows (Jones, 2001; Harris, 2003). What was pushed to the margins was the time to reflect on and to consider, for example, the content and quality of professional practice, actions and judgements which were not so easily monitored and measured.

This had its roots in the 1980s. Thatcher was distrustful of public service professionals, including social workers (Harris, 2003, p. 36), who she saw as selfserving, and viewed public services as wasteful and inflexible. Value for money (VFM) was to be delivered through the three Es of economy, efficiency and effectiveness and the private sector was favoured as the vehicle to deliver VFM. It was an assumption which was maintained by Tony Blair and his advisors (Le Grand, 2003) when Blair became prime minister and further ratcheted up by the Conservative-led governments from 2010 onwards. For the post-1997 New Labour governments, with continuing support for much of the neoliberalist project, there was also the intention to increasingly drive change from the centre of government (Barber, 2007).

\section{The impact of inquiries and inspection}

The lack of trust in social workers was partly generated by the inquiries and reviews into deaths of children as a consequence of abuse and neglect. Indeed it was the first inquiry which was held in public and widely reported by the media which set the tone of the blame culture (Warner, 2015; Shoesmith, 2016; Gibson, 2019) which was to hit social work and which still impacts on and shapes social work practice and the workloads of social workers in children's, and now also adults', services, generating a self-reinforcing and potentially distorting moral panic as described much earlier by Cohen (1973).

The 1973 inquiry into the death of Maria Colwell (Colwell Report, 1974) focussed firmly on Maria's social worker who was described by the inquiry chair as the 'defendant' (Butler and Drakeford, 2011, p. 123). It led to the first iteration of the 
child protection policies, procedures and processes which have come to dominate social work with children amid a blame culture and which has promoted defensive practice. It has consumed increasing proportions of the time of children's and adults' social workers in the statutory and voluntary sectors with the requirement to prepare reports for child protection investigations, case conferences, core group meetings and care proceedings in the courts. As discussed later, there has been a similar recent trend in adult social services.

The inquiries and reviews themselves escalated in number and length throughout the 1980s and beyond (Munro, 2004) leading to the decades of the 1980s and 1990s being described as 'the age of inquiry' (Stanley and Manthorpe, 2004)). They produced recommendations generating more statutory guidance and more local procedures (Rawlings et al, 2014) all of which required more monitoring and auditing of practice, creating agencies where a bureaucratic compliance culture trumped a commitment to develop professional practice and judgement (Munro, 2019).

The blame culture has continued, and indeed been made more intense, by the media's extensive, albeit selective and partial, occasional coverage of child deaths in the 2000s, including the death of eight year old Victoria Climbie in 2000 (Laming, 2003) and Peter Connelly ('Baby P') in 2007. Local MPs and David Cameron when the leader of the opposition have sought to make party political capital out of the tragedy of a child's death (Jones 2014). They used the deaths of children to portray and promote a generalised conclusion about the failure of social work and children's social services (Cameron 2015) despite research indicating that fewer children are known to die as consequence of abuse and neglect in the UK than elsewhere (Pritchard and Williams, 2010).

The increase in external inspections of services by national inspectorates since 2000 has also fuelled the blame culture as inspectors moved away from advising on and promoting best practice to hit-and run inspections where the main output was a ratings judgement. This, alongside national league tables and naming and shaming by government ministers, resulted in inspections being experienced as intimidating and destructive (Puffet, 2013).

\section{The legacy of legislation}

The blame culture (Warner, 2015; Shoesmith, 2016; Gibson, 2019) has impacted on practice and management, but in the UK it is legislation which largely determines the scope and remit of the personal social services. As discussed above, it was the welfare state legislation of the 1940s which provided the platform on which the initially fragmented personal services were built which the 1970 Local Authority Social Services Act brought together within social services departments in England and Wales and with the 1968 Social Work Act having a similar effect in Scotland. 
However, the personal social services in England started to fragment again in the 1990s as a consequence of two Acts which took children's and adults' social services in differing directions and with different structures and management requirements. The 1989 Children Act consolidated and revised private and public law concerning children. It was built on the principle that it was the welfare of the child which was paramount, that the views of children should be taken into account in making decisions, that the assumption should be 'no order' unless a court order was clearly necessary, and that parents had responsibilities as well as rights. The Act promoted partnership working with families to assist 'children in need' or who were 'looked after' by local authorities, and gave a responsibility to local authorities to 'safeguard and promote the welfare' of children. There was nothing in the Act which chimed with the Thatcher Conservative government's ambitions to favour private sector provision over public services. There was, however, a considerable commitment from central government and the civil service to drive the implementation of the Act and the changes in practice and policy it heralded, with ten volumes of guidance totalling just under 1.000 pages.

In contrast, the 1990 NHS and Community Care, following the 1987 Griffiths Report (Griffiths, 1988) on community care, fitted well with the Thatcher philosophy that competitive markets drove the three Es of economy, efficiency and effectiveness, and that consumer choice across a range of services and providers would promote value for money. For the local authority personal social services for adults it required a separation between assessment and the arranging and purchasing of services, ('care management'), from the provision of social care services such as residential and domiciliary care, which, through government rigging of the market to favour private care providers, was largely to be provided by private for-profit companies (Jones, 2019b).

The consequence of the different philosophies and requirements of the 1989 and 1990 Acts was that a separation arose within social services departments with different divisions for children's services and adults' services with social workers either working in children's services or in adults' services teams.

This separation was taken much further following the 2004 Children Act. This Act has often been assumed to be a consequence of the findings of the inquiry into the killing of seven year Victoria Climbie (Community Care, 2005; NSPCC, 2019). However, there was nothing in the inquiry report by Lord Laming (Laming 2003) which required the abolition in England of social services departments and the creation of separate children's services departments, to be headed by a director of children's services (initially mainly the former directors of education) combining local authority (increasingly residual) responsibilities for schools and education with children's social work and social care responsibilities. The fall-back position for local authority adult social work and social care was the creation of a separate department of adult services led by a director of adult social services (usually the former director of social services). 
What had generated this major and fundamental change was the ambition of the Blair-led New Labour government to drive integration across public services. For children the experience of 'Sure Start' for young families (Eisenstadt, 2011), the 'Every Child Matters' agenda (HM Treasury, 2003; Batty, 2005), and success of, for example, inter-agency and multi-professional youth offending teams (YOTs) established by the 1998 Crime and Disorder Act, all pointed towards bringing local authority education and children's social work and care services together. It also reflected a lack of confidence and scepticism by a number of leading Labour politicians about the contribution of social work (Purcell, 2020; Jones, 2020 which they saw, however erroneously and unfairly, as based on a 'deficit model' in the assessment of children and families rather than recognising and promoting capacity and competence.

After 35 years of bringing local authority personal social services together within one department, with social work as the primary profession and directors of social services who were almost invariably social worker qualified and experienced, there was a return to separate departments for children and adults with no requirement or expectation that it would be social workers who would be senior managers and the service leaders. This fundamental change in England placed social work and the personal social services in a position quite a different from those Scotland, Wales and Northern Ireland which still retained social services structures which span children and adults.

In the 2010s the differentiation between England and the other UK nations has been taken further with the government favouring and funding non-university foreshortened education and training of children's social workers separate from the generic initial professional qualifying education for all social workers, despite this being against the recommendations by the Social Work Reform Board (2012) and the House of Commons Education Committee (2017).

Social work education and qualifications across the UK had developed from the Certificate of Qualification in Social Work (CQSW) introduced in 1971, with an employer-led Certificate of Social Service (CSS) introduced in 1975 primarily for other workers in the personal social services. The CQSW and CSS were brought together in 1989 within a Diploma for Social Work, and with social work made a graduate profession in 2003. Throughout all these changes, however, the initial qualifying training was generic and was relevant for, and applied to, all social workers across the UK. It was post-qualifying education and qualifications which was to support specialised practice and roles. The government in England, with its support of Frontline, the contentious specialist, fore-shortened, one year qualifying training for children's social workers (Stevenson, 2018), has moved away from the other UK nations in its favouring of the potential career-limiting initial qualifying specialisation of social workers.

So, in England by 2020 there are now separate local authority departments for children and adults and separate specialised initial education for children (and mental 
health) social workers. The two major building blocks put in place fifty years ago of an integrated local authority personal social services department and generically educated professional social workers are now being deconstructed.

\section{Privatisation and commercialisation}

The other form of deconstruction in England, but not mainstream for the other UK nations, is the drive to privatise social work and the personal social services. For most adult social care provision this has already been achieved as a consequence of financial levers favouring the out-sourcing of public services, including adult residential care, introduced by the 1980s and 1990s Conservative governments and the 1990 NHS and Community Care Act. It was a process continued by the 1997-2010 New Labour governments under the heading of public-private partnerships with, in particular, the private sector funding capital developments and from which they are now reaping rich returns in interest and facilities management payments (BBC, 2018).

Children's services in the 1990s and beyond were largely immune from the encroachment of for-profit commercial companies but this has substantially changed. In England 73 per cent of children's home are now owned and managed by private companies (Bradbury, 2018) and 39 per cent of children in foster care are in placements purchased from private foster care companies (Ofsted, 2019). It has been calculated that more than $£ 220$ million pounds a year in England (Jones 2019a) is being taken out of public funding of children's social services as profits by the owners of private companies.

Until recently, however, statutory social work services for children and adults could not be contracted out to private companies or other non-public sector organisations. Private companies had already made significant in-roads in to social work through the provision of agency social workers. Eighteen per cent of local authority children's social workers in England are provided through for-profit employment agencies (Department for Education, 2019). The 2014 Social Care Act and the changes in statutory regulations in 2014 for children's social services now allow the contracting-out of statutory children and adult social work services to other service providers including commercial companies (Jones, 2019b).

For children's social work this means that children in need and child protection assessments, setting and managing children in need and child protection plans, and determining whether to initiate court care proceedings and if orders are made then deciding where and with whom a child can live can all be contracted-out to private companies.

The 2014 Social Care Act, however, does not allow adult protection to be out-sourced from local authorities. Why child protection can be privatised but not adult protection probably reflects differences of view about accountability, 
responsibility and safe delivery between ministers, their advisors and senior civil servants in the Department for Education and the Department of Health.

\section{Looking back: The contribution of social work and social workers}

Social workers in the UK can make credible claims that their contribution during the past 50 years has been at the vanguard of constructive change, and much of it has been driven by the social science, and sociology, foundations which have been integrated and integral to their education and understanding.

Five developments, in particular, have had social workers centre stage.

First, the 1970s disputes about whether social work should aspire to be a profession have partly been resolved by social workers redefining their professional role. No longer are the criteria about holding jealously guarded professional knowledge and the expert knows best. The special characteristic of social work now is about enabling and facilitating and working in partnership with people and with communities co-producing resources and solutions to difficulties. Figure 1 shows how the professional continuum has changed.

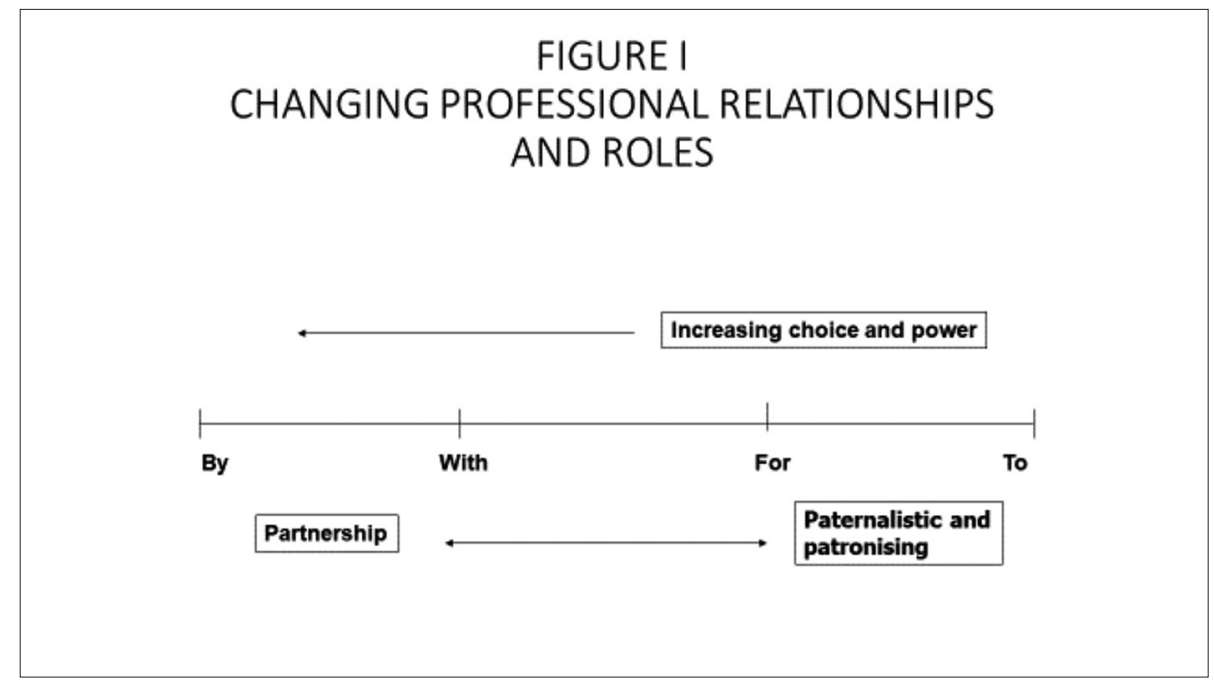

Secondly, social workers and the personal social services during the past 50 years have been active in the move away from institutional confinement to community care to recognising and acknowledging disabled and older people, and younger people and families, as active contributing citizens with capacity, strengths and expertise based on experience, as noted in Figure 2. 


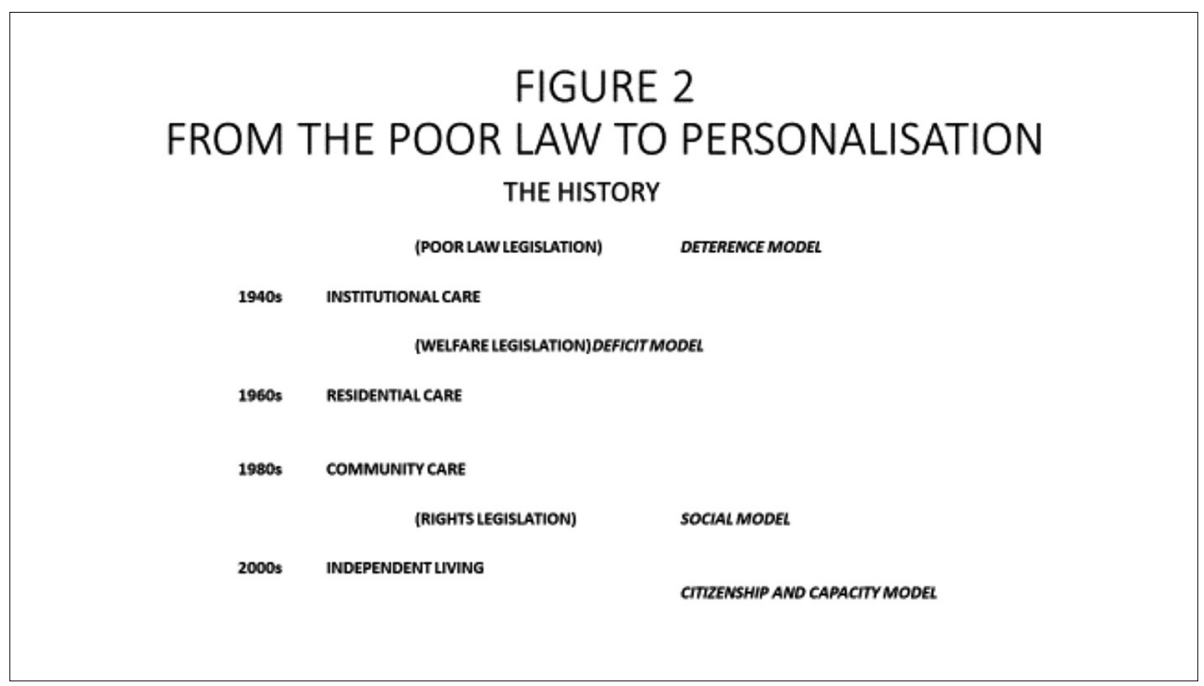

Thirdly, social workers have acted to change policies and practice with legislation following rather than leading change. It was the creation by disabled people of the social model of disability and the promotion of independent living which influenced social workers and led them ahead of the enabling legislation to develop the processes to transfer cash to disabled people so that they might have more choice and control in their lives. The 1996 Community Care (Direct Payments) Act in England and Wales followed the schemes which were developed to transfer local authority funding to third party organisations which was then passed to disabled people. The 2015 Social Care Act, with its promotion of personal budgets, has its roots in the developments in the early 1990s, developments which were ahead of the recommendations in the 1987 Griffiths Report on community care and the 1990 NHS and Community Care Act which fell short of permitting cash transfers to disabled people.

Another example of social work practice and personal social services policies shaping future legislation was the development in the 1950s and early 1960s (Donnison 1965; Packman 1975) of social work to assist families beyond the scope of the 1948 Children Act which was then legislated for by the 1963 Children and Young Persons Act.

Fourthly, social workers have been at the forefront of actions to tackle abuse and exploitation of children and, more recently, of adults with child (and adult) protection having broadened to encompass a wider range of risks and dangers, as noted in Figure 3. 


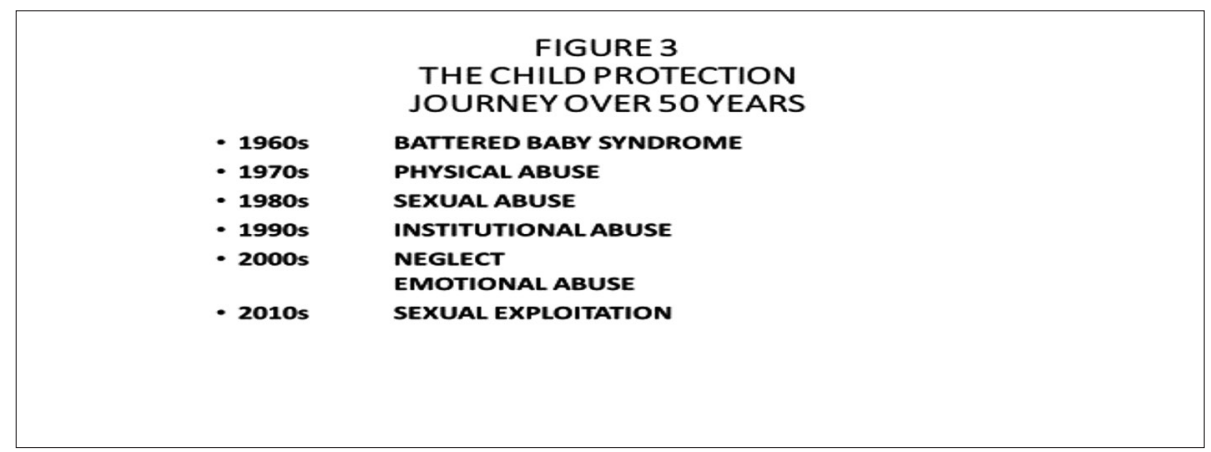

The above claims for a special contribution made by social work and social workers across the UK in the past fifty years may be contentious, in part because none of these developments have been achieved and secured by social workers on their own. This, however, rather than being seen as a criticism should be viewed as a strength as it is through working in collaboration and partnership with others that agendas have been shaped and change secured. Building and working within alliances is itself a professional competence and commitment for social workers.

There are also traditions within social work which are not always shared by other professionals. One of the criteria for a long-standing traditional profession such as the law or medicine is that the professional stands alone with their knowledge and competence. Within social work, however, it has been teams and teamwork which were embedded within the Seebohm proposals fifty years ago, along with the process of reflective supervision to review and enhance understanding and action.

There are also stronger practice models and practice tool kits today than fifty years ago, based on strengths-based models of assessment and action. No longer would a description of providing unstructured and unspecified 'social work support' be likely to be seen as adequate or acceptable. Having more clarity and coherence, and more transparency and explicitness, in assessments and action planning is positive, as is the Professional Capabilities Framework (BASW, 2020) developed by the Social Work Reform Board with its continuum of competences to be built and demonstrated throughout a social worker's career (Social Work Reform Board, 2012).

\section{Looking askance: The current skews}

The commitment that social work should be practised humanely, and with the quality of relationships between social worker and those they are seeking to help, is at the core of the 'reimagining' of social work which Featherstone and colleagues have argued is necessary (Featherstone et al, 2014 and 2018). It reflects concerns 
that social work has become skewed in its focus and activities.

First, the dominance of risk assessments and risk management, and what might be argued to be risk aversion, has skewed social work with children and families and with adults. Its roots are in 1970s, but in the past decade the extent of child protection activity has increased exponentially. For example, in 2009-20010 there were 89,300 1989 Children Act Section 47 investigations in England and in 20182019 this had increased by 125 per cent to 201,170 investigations. On 31 March 2008 there were 29,200 children in England with child protection plans and by 31 March 2019 this had increased by 86 per cent to 52,600 children. For 86 per cent of these children the concerns were not about physical or sexual abuse but about neglect (48 per cent) and emotional abuse (38 per cent), concerns which had a high correlation with deprivation (Bilson and Martin, 2016; Bywaters et al, 2016; Hood et al, 2016). Rather than receiving a child protection response these are the concerns which might have been addressed in the past through seeking to assist families rather than the threat and surveillance ingrained within child protection procedures.

There has been a similar, albeit more recent, increase in adult protection activities. For example, in 2015-2016 there were 107,970 2014 Care Act Section 42 adult protection investigations which had increased to 143,050 in 2018-2019. Deprivation of Liberty (DOLS) assessments have increased from 7,157 in 2009-2010 to 143,050 in 2108-2019.

Secondly, the context of politically-chosen austerity and cuts targeting poor children and families, disabled people, and public services have led to social workers increasingly being captured in rationing assistance rather than providing help and creating and mobilising resources within communities, as envisaged by the Seebohm Committee.

Thirdly, social workers and adult personal social services are being increasingly seen by government as a solution to the crisis of NHS pressures rather than as having a valued and viable contribution to make in their own right. It is why the arguments for merging adult personal social services into health services has every danger of marginalising social work's contribution beyond keeping and getting people out of hospital and carrying the responsibility for assessing risk with blame then to be allocated if there are awful incidents and events in the future.

Fourthly, viewing the personal social services as the fourth emergency service (Loughton, 2012) may be seen to give status and promote support for social work services but it reflects a change of vision and role from what social workers and the personal social services sought to contribute. Being the ambulance at the bottom of the cliff is quite a different aspiration from the Seebohm committee's view that social workers and the personal social services would be working within communities to prevent crisis and to promote well-being.

Fifthly, political control. It was the government's proposals injected into the Children and Social Work Bill, which preceded the 2017 Children and Social Work Act, which brought to the forefront of attention the Conservative government's 
intentions in England to have control of who could be a social worker, how they were to be educated and by who, and with power to be given to the Secretary of State for Education to set aside statutory rights of children and statutory responsibilities of children's social services. The proposals were defeated following concerted, coordinated and collective campaigning by children's and social work organisations (Tunstill and Willow, 2017) but with the Secretary of State for Education still having powers over Social Work Education, the regulator of social workers in England.

Sixthly, the focus on tasks, targets, tick boxes and tools and techniques have emphasised proceduralised practice over professional practice. And yet it is the quality of the human interaction between social workers and those they seek to assist which remains crucial. This is especially important for those who are in the midst of crisis and what have been called psychosocial transitions (Murray Parkes, 1998). Whether it is relationship breakdown and loss of relationships, limited or lessening capacity as a consequence of impairment, illness, accident or ageing, or major challenges and confrontations from, for example, increasing poverty, becoming homeless or being abused, having an empathetic confidante who does not ignore or distance themselves from the pain but may be able to create some space, calm and structure to find a way forward remains core to the contribution of professional social work. Assessing risk and risk management is a part of the task, particularly within statutory services, but it should not be the limited and blinkered only contribution which social workers are allowed to make.

\section{Looking across: England and the UK in comparative context}

the International Federation of Social Workers' (IFSW) definition of social work stresses that social work is about social change, development and empowerment and based on principles of social justice, human rights and respect for diversities, and states that 'social work engages people and structures to address life challenges and enhance wellbeing' (IFSW, 2014). It is a description of a profession with a strong values base and which encompasses work with individuals but also work with communities, and with an inevitable and necessary political as well as a personal focus.

Social work, however, is shaped by its historical, political, ideological and geographical context and cultural traditions (Munday 1983, 1989; Cannan et al, 1992; Lyons and Lawrence, 2006). Where social work is mainly embedded within NGOs it is not so heavily shaped by government legislation and regulation and there is greater opportunity and potential to promote the political alongside and interwoven with the personal. It may also have more of a community focus than the individualised focus which has predominated in the UK, despite the vision of the Seebohm Committee.

In the UK since the 1940s, and to some extent before, social work has benefitted 
from being resourced by the state as a public service. It has expanded both in size and in remit. But it has also had the restriction that most social workers in the UK are employed in local and central government agencies with their roles defined by Parliament. The scope as state employees to fulfil the political implications and imperatives of the global definition of social work is limited and leaves individual and isolated social workers vulnerable as employees if they challenge statutory agency and government policies. It is all the more important, therefore, that social workers in the UK create and contribute to a strong collective voice which comments on and can confront discrimination and oppression whilst through their employment seeking to minimise the marginalisation and minimisation of those they seek to assist.

However, even in countries where the state has taken a significant role in shaping and regulating social work it has not always produced the same emphasis on risk and rationing which has come to dominate social work in the UK and where assessment rather than direct work with people takes much of the time of social workers contrasting, for example, with social pedagogues in Europe. Other contrast are the increasing central government shaping and regulation of social work and the personal social services in the UK compared to the greater decentralisation in other countries with local authorities and communities more empowered to respond to local circumstances and need (Hill, 1991).

But even between the devolved administrations of the four UK countries significant differences of emphasis and horizons have emerged. The 2014 Social Services and Well-being (Wales) Act emphasises preventative services to tackle emerging difficulties early and to promote well-being within communities. Scotland is focussing on health and social care partnerships to include NHS boards, local authorities and other providers to move investment into local community services (Scottish Government, 2016) and with the Children and Young People (Scotland) Act 2014 requiring local authorities and health boards to prepare triannual children's services plans. In England there has been concern about the government's failure to involve and engage with those providing personal social services (House of Commons Education Select Committee, 2017) whereas Scotland, for example, has a Social Work Services Strategic Forum which includes the Scottish Government, local authorities, trade unions, social work education providers, the Scottish Association of Social Workers and others. The Forum jointly produced a five year vision and strategy for social work and the personal social services (Social Work Strategic Forum, 2015). In Northern Ireland the suspension of the Stormont Assembly has limited legislative and policy reform. But the legacy of the Troubles have not only had an impact in terms of political conflict and personal trauma but also has had an impact on social work. For example, community development which was promoted by the Seebohm Committee had a continuing higher profile in Northern Ireland social services than elsewhere in the UK (Heenan, 2004) as had an explicit focus on social justice (Pinkerton and Campbell, 2002) with the chief social worker for Northern Ireland recently emphasising 'how social workers use their skills to work 
effectively across boundaries and borders that can divide people' (Holland, 2019).

There are also very explicit and concrete differences which have emerged between the UK's nations. For example, unlike elsewhere in the UK, Scotland through the Community Care and Health (Scotland) Act 2002 introduced free care within residential homes for older people and, unlike in England and Northern Ireland, in Scotland and Wales (as in many European states) it is unlawful to physically assault children as a form of chastisement or punishment.

\section{Looking forward: New issues, new concerns and new opportunities}

What might the future hold for social work and the personal social services across the UK? The outcome of the 2019 General Election with a Conservative government with a workable majority in place and with next election not scheduled until May 2024 is already having the consequence of continuing politically-chosen austerity being targeted at poor children and families and at disabled people through deepening cuts to welfare benefits. Despite promises of more money for the police, NHS and schools the amounts being promised will hardly compensate for the reductions in funding to these services since 2010. For local authorities and children's and adults' social services there has been no commitment given to rein back or reverse the funding reductions (Jenkins, 2019).

The beginning of 2020 is also seeing the UK's exit from the European community with no trade agreement in sight and with a commitment to severely restrict mobility of labour. There are three implications for social work and the social services. First, the UK government may be driven to a trade agreement with the United States which could lead to the further opening up of public services to American private companies. Second, especially for social care services, there is likely to be a major workforce shortage impacting on the staffing of care homes and domiciliary care services (Carter, 2020). Third, there is likely to be an increasing divergence for social work and the personal social services between the four UK nations with the politics and aspirations of Scotland, Wales and Northern Ireland increasingly distinct from those of Westminster and Whitehall.

Looking more widely beyond the parochialism of England, there is likely to be increased population movement as a consequence of global warming leading to climate change with extreme weather and natural disasters, more frequent with floods and famine, and with nationalist governments, as in the UK, corralling migrants. The extremes are already being evidenced with children removed from parents crossing the United States border and with no records kept about where the children and parents are being separately located so that linking them again may be impossible (BBC, 2019). 
For social workers the net of child and adult protection concerns is widening and may widen further. Added to the developing child protection concerns of the past fifty years (see Figure 3) are trafficking and the county-lines drug-related exploitation of young people (Home Office, 2018).

But there is another, potentially sinister, additional category which may be added to child and vulnerable adult protection. Through the 'Prevent' agenda social workers are being drawn in to monitoring and policing those who are active in campaigning for change, such as within the environmental and animal rights movements (Bloom, 2015; Jones, 2015; Dodd and Grierson, 2020). Social workers need to be watchful that they are not drawn into punitive roles as they were in the 1960s when children were taken into care because their families were homeless and with this again having been raised as an issue and danger (Hilditch, 2018).

The other major crisis of 2020 is the chaos created by the coronavirus pandemic. In one sense indiscriminate in who may be infected and who may die, the impact is most significant for those who are already poor and who are less likely to be within communities which can promote protection and minimise the economic and social impact of the disease. It is also a disease where its infection rate has been higher for those public sector and other workers, especially with black and ethnic minority heritance, who through their work have close, and often inadequately protected, proximity to others - such as health and care workers, public transport workers, security and retail workers. And there is the scandal which needs to be investigated of residents in care homes left exposed and vulnerable by a government which was either reckless or careless in its management of the crisis.

There is every possibility that while the pandemic is at its peak, and health, care and other key workers are applauded and celebrated, the residual impact on the economy will, as with the banker-created international and national crisis of 2008, be used as a rationale, an excuse, an explanation, to keep public expenditure low, public services poorly funded, and to disadvantage even more poor people, including those in low paid employment who had roles where they had to remain at work during the peak of the infection crisis.

If these are the dangers, what are the opportunities? First, following the scandal of the collapse of out-sourcing company Carillion with public contracts unfulfilled despite big profits having been taken, and with other privatisation failures (Jones, 2019b), the public has been turning away from trusting the commercial market and is showing greater confidence in public services (YouGov, 2017; Stone, 2019). Possibly the trend towards commercialising and privatising-for-profit social work and social services can be reversed.

Second, Ofsted has been reporting how the most successful children's social services have been returning to community-based teams with fewer hand-overs of cases between different types of teams. Better performing services have had stable leadership and workforces not dependent on short-term agency workers and managers, have built stronger and continuing relationships with children and 
families, and with the other professionals and administrative workers being located in teams alongside social workers (Ofsted 2018a, 2018b, 2018c, 2018d, 2019). The integration of adult services workers alongside children's services workers within teams based on communities reflects a modern iteration of the Seebohm Committee's ambitions to have an integrated community-based service albeit with a new contemporary solution to the generic-specialist worker debate (children's and adults workers together in one team working with children and families).

Third, for adults facing illness, impairment or the frailties of ageing, genome medicine offers a prospect of longer life spans of better health, and along with the potential of new technologies to aid and assist independent living. But even with the advancement of technology there will still be a need for confidantes - social workers - who can help through the difficult times of psychosocial transitions, to create and mobilise community resources, and to protect when necessary.

So the future offers threats and opportunities which are likely to impact on social work and social workers and those with whom they work. If there is one overriding message from the past fifty years it is that social workers have at times, informed by their roots in sociology and the social sciences, had a significant impact on shaping polices and the future when they have acted collectively and in alliances with others. It is a message and mission which remains relevant today.

\section{Note}

Professor Jones's book From Feast to Famine to the Future: A History of the Personal Social Services in England will be published this month by Pagrave Macmillan

\section{References}

Bailey, R. and Brake, M. (1975) (Eds.) Radical Social Work. London: Edward Arnold Brake, M. and Bailey, R. (1980) (Eds.) Radical social work in practice. London: Edward Arnold, Bamford, T. (1993) Information on Social Services in Northern Ireland. in B. Munday (Ed.) European Social Services, European Institute of Social Sciences. Canterbury, University of Kent (pp. 392-395

Bamford, T. (2015) A Contemporary History of Social Work: Learning from the past. Bristol: Policy Press

Bamford, T. (2020) Social work with offenders. in T. Bamford and K. Bilton (Eds.) Social Work: Past, Present and Future. Bristol: Policy Press (pp. 173-189)

Baraclough, J., Dedman, G., Osborn, H. and Willmott, P. (1996) 100 Years of Health Related Social Work 1895-1995, Birmingham, BASW 
Barber, M. (2007) Instruction to Deliver: Fighting to transform Britain's public services. London: Methuen

Barclay Report (1982) Social Workers: Their role and tasks. London: Bedford Square Press

BASW (2020) Professional Capabilities Framework, https://www.basw.co.uk/professionaldevelopment/professional-capabilities-framework-pcf

Batty, D. (2015) Climbié inquiry: The issue explained. https://www.theguardian.com/ society/2005/aug/05/climbie

BBC (2018) PFI deals 'costing taxpayers billions', https://www.bbc.co.uk/news/ business-42724939

BBC (2019) 'Thousands' more migrant children may have been separated at border, https:// www.bbc.co.uk/news/world-us-canada-46912915

Becker. H. (1967) Whose Side Are We On? Social Problems, 14. 3 , 39-247

Bilson, A. and Martin, K. (2016) Referrals and child protection in England: One in five children referred to children's services and one in nineteen investigated before the age of five, The British Journal of Social Work, 47, 3, 793-811

Bilton, K. (2008) The Formation of the British Association of Social Workers. paper presented to the Social Work History Network, February

Bloom, A. (2015) Police tell teachers to beware of green activists in counter-terrorism talk, https://www.tes.com/news/police-tell-teachers-beware-green-activists-counterterrorism-talk

Bowlby, J. (1953) Child Care and the Growth of Love. London: Penguin Books

Bradbury, J. (2018) The changing picture in the children's homes sector, https:// socialcareinspection.blog.gov.uk/2018/08/22/the-changing-picture-in-the-childrenshomes-sector/

Burnham, D. (2012) The Social Worker Speaks: A history of social workers through the twentieth century. Farnham: Ashgate

Butler, I. and Drakeford, M. (2011) Social Work on Trial: The Colwell Inquiry and the state of welfare. Bristol: Policy Press

Butrym, Z. (1968) Medical Social Work in Action. London: Bell

Butrym, Z. 1976) The Nature of Social Work. Basingstoke: Macmillan

Bywaters, P., Bunting, L., Davidson, G., Hanratty, J., Mason, W., McCartan, C. and Steils, N. (2016) The relationship between poverty, child abuse and neglect: An evidence review. 3 March, Joseph Rowntree Foundation, https://www.jrf.org.uk/report/relationshipbetween-poverty-child-abuse-and-neglect-evidence-review

Campbell, J. (2007) Social work, political violence and historical change: Reflections from Northern Ireland, Social Work and Society, 5, 3, https://www.socwork.net/sws/article/ view/143/512

Cameron, D. (2015) My vision for a smarter state' 11 September, https://www.gov.uk/ government/speeches/prime-minister-myvision-for-a-smarter-state

Cannan, C., Berry, 1. and Lyons, K. (1992) Social Work in Europe. Basingstoke: Macmillan

Carter, C. (2020) Post-Brexit migration plans would deepen social care pressures, say government advisers, https://www.communitycare.co.uk/2020/01/30/post-brexit- 
migration-plans-deepen-social-care-pressures-say-government-advisers/

Clarke, J. and Newman, J. (1997) The Managerial State. London: Sage

Cohen, S. (1973) Folk Devils and Moral Panics: The creation of the mods and rockers. London: Paladin

Colwell Report (1974) Report of the Committee of Inquiry into the Care and Supervision provided by local authorities and other agencies in Relation to Maria Colwell and the co-ordination between them. London: Her Majesty's Stationery Office

Community Care (2005) Child protection, https://www.communitycare.co.uk/2005/03/15/ child-protection-3/

Cooper, D. (1967) (Ed.) Psychiatry and Anti-Psychiatry. London: Paladin

Cooper, J. (1983) The Creation of the British Personal Social Services 1962-1974. London: Heinemann Educational Books

Corrigan, P. and Leonard, P. (1978) Social Work Practice under Capitalism: A Marxist approach. London: Macmillan

Cromarty, H. (2018) Social Work Regulation (England).Briefing paper CBP07802, 22 June. London: House of Commons Library

Davis, A. (2008) Celebrating 100 Years of Social Work at the University of Birmingham. Birmingham, University of Birmingham

Day, P. (1981) Social Work and Social Control. London: Tavistock Publications

Department for Education and Science (1966) A Plan for Polytechnics and Other Colleges. London: HMSO

Department for Education (2019) Children's Social Work Workforce 2018, https://www.gov. uk/government/statistics/childrens-social-work-workforce-2018

Dodd, K. and Grierson, J. (2020) Terrorism police list Extinction Rebellion as extremist ideology, https://www.theguardian.com/uk-news/2020/jan/10/xr-extinction-rebellionlisted-extremist-ideology-police-prevent-scheme-guidance

Dominelli, L. (1996) Deprofessionalizing social work: Anti-oppressive practice, competencies and postmodernism, The British Journal of Social Work, 26,.2, 153-175

Dominelli, L. (1997) Anti-racist Social Work: A challenge for white practitioners and educators. Basingstoke: Macmillan

Dominelli, L. and McLeod, E. (1998) Feminist Social Work. Basingstoke: Macmillan

Donnison, D. (1965) The development of casework in a children's department. in D. Donnison and V. Chapman, (Eds.) Social Policy and Administration: Studies in the development of social services at the local level. London: George Allen and Unwin (pp. 94-119)

Donnison, D. (1975) Taking decisions in a university. in D. Donnison, V. Chapman, M. Meacher, A. Sears, and K. Urwin (Eds.) Social Policy and Administration Revisited. London: George Allen and Unwin (pp. 253-285)

Doward, J. (2019) Chris Grayling's privatisation of probation service 'a disaster', https:// www.theguardian.com/politics/2019/jun/30/chris-grayling-probation-privatisationdisaster

Eisenstadt, N. (2011) Providing a Sure Start: How government discovered early childhood. 
Bristol: Policy Press

Etzioni, A. (1969) (Ed.) The Semi-Professions and Their Organisation: Teachers, nurses, social workers. New York: Free Press

Featherstone, B., White, S. and Morris, K. (2014) Re-Imagining Child Protection. Bristol: Policy Press

Featherstone, B., Gupta, A., Morris, K. and White, S. (2018) Protecting Children: A social model. Bristol: Policy Press

Ferlie, E., Pettigrew, A., Ashburner, L. and Fitzgerald, L. (1996) The New Public Management in Action. Oxford, Oxford University Press

Frost, N. (2005) Professionalism, partnership and joined-up thinking, Dartington, Research in Practice

General Social Services Action Group (1992) General Social Services Consultation Papers, May. London: National Institute for Social Work

Gibson, M. (2019) Pride and Shame in Child and Family Social Work: Emotions and the search for humane practice. Bristol: Policy Press

Goffman, E. (1961) Asylums: Essays on the social situation of mental patients and other inmates, Harmondsworth, Penguin

Goldstein, H. (1973) Social Work Practice: A unitary approach. Columbia: University of South Carolina Press

Griffiths, Sir R. (1988) Community Care: Agenda for Action: A Report to the Secretary of State for Social Services by Sir Roy Griffiths. London: HMSO

Hadley, R. (1982) A case for neighbourhood-based social work and social services. in Barclay Report (1982) Social Workers: Their role and tasks. London: Bedford Square Press (pp. 219-235)

Hadley, R. (1987) A Community Social Worker's Handbook. London: Routledge

Hall, P. (1976) Reforming the Welfare: The politics of change in the personal social services. London: Heinemann

Halmos, P. (1978) The Personal and the Political: Social work and social action. London: Hutchinson

Hamilton, G. (1956) Theory and Practice of Social Case Work. New York: Columbia University Press

Harris, J. (2003) The Social Work Business. London: Routledge

Heenan, D, (2006) Learning lessons from the past or re-visiting old mistakes: social work and community development in Northern Ireland. British Journal of Social Work, 34.6 (pp. 793-809

Herzberg, F. (1968) Work and The Nature of Man. London: Staple Press

Hiddleston, V. (2006) The Social Work (Scotland) Act. Paper presented at University of Edinburgh, 3 November

Hilditch, M. (2018) Shelter warns of legal action over threats to remove children from homeless parents, https://www.insidehousing.co.uk/news/news/shelter-warns-of-legalaction-over-threats-to-remove-children-from-homeless-parents-58584

Hill, M. (1991) Approaching with Caution: Social work and the European Community from a 
British perspective. London: Jessica Kingsley (p.20)

HM Treasury (2003) Every Child Matters. Cm 5860. London: Stationery Office

Holland, S. (2019) Social workers have a duty to represent and support NI's marginalised in society, https://www.northernireland.gov.uk/node/38930

Hollis, F. (1964) Casework: A psychosocial therapy. New York: Random House

Holman, B. (1998) Child Care Revisited: The Children's Departments 1948-1971. London: Institute of Childcare and Social Education UK

Holman, B. (2001) Champions for Children: The lives of modern child care pioneers. Bristol: Policy Press

Home Office (2018) Criminal Exploitation of children and vulnerable adults: County lines guidance. London: Home Office

Hood, R., Goldacre, A., Grant, R. and Jones, R. (2016) Exploring Demand and Provision in English Child Protection Services. British Journal of Social Work, 46.4, 923-941

House of Commons Education Committee (2017) Social work reform: Third Report of Session 2016-17. HC 201. London: House of Commons

IFSW (2014) Global Definition of the Social Work Profession, https://www.ifsw.org/globaldefinition-of-social-work/

Ivory, M. (2010) BASW's beginnings. Profession al Social Work, June, p. 23

Jenkins, S. (2019) This was the Queen's speech - as written by Dominic Cummings, https:// www.theguardian.com/commentisfree/2019/dec/19/johnson-cummings-new-politicspopulism-optimism

Jones, C. (2001) Voices from the front line: state social workers and New Labour, British Journal of Social Work, 31.4, 547-562

Jones, D. (2018) (Ed.) Regulation of Social Work and Social Workers in the United Kingdom. Birmingham, BASW

Jones, R. (2014) The Story of Baby P: Setting the record straight. Bristol: Policy Press

Jones, R. (2015) Is 'thought abuse' about to become the fifth category of child abuse?, https://www.communitycare.co.uk/2015/11/06/thought-abuse-become-fifth-categorychild-abuse/

Jones, R. (2019a) Outsourcing children's services isn't just wrong - it's a waste of money, https://www.theguardian.com/society/2019/aug/07/outsourcing-childrens-serviceswrong-waste-money

Jones, R. (2019b) In Whose Interest? The privatisation of child protection and social work. Bristol: Policy Press

Jones, R. (2020) From Feast to Famine to the Future: A history of social work and the personal social services in England 1970-2020. London: Palgrave Macmillan

Laming, Lord (2003) The Victoria Climbie Inquiry. Cm 5730, Norwich, The Stationery Office

Le Grand, J. (2003) Motivation, Agency, and Public Policy: Of knights and knaves, pawns and queens. Oxford, Oxford University Press

Lipsky, M. (1980) Street-level Bureaucracy: Dilemmas of the individual in public services. New York: Russell Sage Foundation.

Loughton, T. (2012) Tim Loughton Addresses Community Care Live, https://www.gov.uk/ 
government/speeches/tim-loughton-addresses-community-care-live

Lyons, K. and Lawrence, S. (2006) Setting the scene: Social work and Europe. in K. Lyons and S. Lawrence (Eds.) Social Work in Europe: Educating for change. Birmingham, Venture Press, p. 7

Malin, N. (2020) De-Professionalism and Austerity: Challenges to the public sector. Bristol: Policy Press

Maslow, A. (1954) Motivation and Personality. New York: Harper

McLauglin, K. (2008) Social work, Politics and Society: From radicalism to orthodoxy. Bristol: Policy Press

Munday, B. (1989) Introduction. in B. Munday. (Ed.) The Crisis in Welfare: An international perspective on social services and social work. London: Harvester Wheatsheaf ( p. 4)

Munday, B. (1993) Introduction. in B. Munday (Ed.) European Social Services. Canterbury: European Institute of Social Services, University of Kent, p. ii

Munro, E. (2004) The Impact of Child Abuse Inquiries since 1990. in N. Stanley and J. Manthorpe (Eds.) The Age of Inquiriy: Learning and blame in health and social care. London: Routledge,

Munro, E. (2019) Decision-making under uncertainty in child protection: Creating a just and learning culture, Child and Family Social Work, 21, 1, 123-130

Niechcial, J. (2010) Lucy Faithful: Mother to hundreds. self-published (p 90)

Murray Parkes, C. (1998) Coping with Loss. Oxford: Wiley-Blackwell

Northern Ireland Social Care Council (2019) Annual Report 2018-2019, Belfast, Northern Ireland Social Care Council

NSPCC (2019) History of child protection in the UK, https://learning.nspcc.org.uk/childprotection-system/history-of-child-protection-in-the-uk/

Oakley, A. (2014) Father and Daughter: Patriarchy, gender and social science. Bristol: Policy Press

Ofsted (2018a) Hertfordshire: Inspection of children's social care services. Manchester, Ofsted

Ofsted (2018b) East Sussex County Council: Inspection of children's social care services. Manchester, Ofsted

Ofsted (2018c) Leeds: Inspection of children's social care services. Manchester: Ofsted

Ofsted (2018d) Essex County Council: Inspection of children's social care services. Manchester: Ofsted

Ofsted (2019a) Hampshire County Council: Inspection of local authority children's services. Manchester: Ofsted

Ofsted (2019b) Fostering in England 2017-2018, https://www.gov.uk/government/ publications/fostering-in-england-1-april-2017-to-31-march-2018/fostering-in-england2017-to-2018-main-findings

Packman, J. (1975) The Child's Generation: Child care policy from Curtis to Houghton. Oxford: Basil Blackwell

Parker, R. (1990) Safeguarding Standards. London: National Institute for Social Work

Parsloe, P. (1981) Social Services Area Teams. London: George Allen and Unwin

Payne, M. (2002) The Role and achievements of a professional association in the late 
twentieth century: The British Association of Social Workers 1970-2000. British Journal of Social Work, 32, 8, 1 969-995

Perlman, H. (1957) Social Casework: A problem-solving process. Chicago: University of Chicago Press

Pinker, R. (1982) An alternative view. in Barclay Report (1982) Social Workers: Their role and tasks. London: Bedford Square Press (pp. 236-262)

Pinkerton, J. and Campbell, J. (2002) Social Work and Social Justice in Northern Ireland: Towards a New Occupational Space, British Journal of Social Work, 32, 6, 723-737

Pritchard, C. and Taylor, R. (1978) Social Work: Reform or revolution? Henley-on Thames: Routledge and Kegan Paul

Pritchard, C. and Williams, R. (2010) Comparing possible 'child-abuse-related-deaths' in England and Wales with the major developed countries 1974-2006: Signs of progress? British Journal of Social Work, 40, 6, 1700-1718

Purcell, C. (2020) The Politics of Children's Services Reform: Re-examining two decades of policy change (1997-2020). Bristol: Policy Press

Puffett, N. (2013) NCAS Conference: Tough OFSTED Inspections Having Detrimental Effect of Child Services Standards, https://www.cypnow.co.uk/news/article/ncas-conferencetough-ofsted-inspections-having-detrimental-effect-on-child-services-standards

Rawlings, A., Paliokosta, P., Maisey, D., Johnson, J., Capstick, J., and Jones, R. (2014) A Study to Investigate the Barriers to Learning from Serious Case Reviews and Identify ways of Overcoming these Barriers: Research report. London: Department for Education

Rivett, G. (1998) From Cradle to Grave: Fifty years of the NHS. London: King's Fund

Report of the Working Party on Social Workers in the Local Authority Health and Welfare Services (1959) Ministry of Health and Department of Health for Scotland. London: HMSO

Robb, B. (1967) Sans Everything: A case to answer. London: Nelson

Rock, P. (1973) Deviant Behaviour. London: Hutchinson

Rogowski, S. (2010) Social Work: The rise and fall of a profession. Bristol: Policy Press

Rolph, S., Atkinson, D. and Walmsley, J. (2003) 'A pair of stout shoes and an umbrella': The role of the Mental Welfare Officer in delivering community care in East Anglia, 1946-1970. British Journal of Social Work, 33, 3, 339-359

Rowbottom, R., Hey, A. and Billis, D. (1974) Social Services Departments: Developing patterns of work and organisation. London: Heinemann

Scottish Government (2016a) Social Work and Social Care Statistics for Scotland. Edinburgh: Scottish Government, Office of the Chief Social Work Adviser

Scottish Government (2016b) Health and Social Care Delivery Plan, December. Edinburgh: Scottish Government

Scottish Social Care Council (2018) SSSC Annual Report and Accounts 2017-2018. Edinburgh: Scottish Social Care Council

Secretary of State for Health (1998) Modernising Social Services: Promoting independence, Improving protection, raising standards. November, Cm 4169. London: The Stationary Office

Seebohm Committee (1968) Report of the Committee on Local Authority and Allied Personal 
Social Services. Cmnd 3703. London: HMSO

Shoersmith, S. (2016) Learning from Baby P: The politics of blame, fear and denial. London: Jessica Kingsley

Simpkin, M. (1979) Trapped Within Welfare: Surviving social work. Basingstoke: Macmillan Stanley, N. and Manthorpe, J. (2004) The Age of Inquiries: Learning and blaming in health and social care. London: Routledge

Social Care Wales (2017) Factsheet: Social Workers on the Register. Cardiff: Social Care Wales Social Care Wales (2019) Annual Report 2018-2019. Cardiff: Social Care Wales

Social Work Strategic Forum (2015) Social Service in Scotland: A shared vision and strategy 2015-2020. Edinburgh: Office of the Chief Social Work Adviser

Social Work Reform Board (2012) Building a Safe and Confident Future: Maintaining momentum. London: Department for Education

Specht, H. and Vickery, A. (1977) (Eds.) Integrating Social Work Methods. London: George Allen and Unwin

Statham, D. (1978) Radicals in Social Work. London: Routledge and Kegan Paul

Stevenson, O. (1981) Specialisation in Social Service Teams. London: George Allen and Unwin

Stevenson, L. (2018) Five years of Frontline: the impact, the debate and the future of fasttrack social work training, https://www.communitycare.co.uk/2018/10/03/five-yearsfrontline-impact-debate-future-fast-track-social-work-training/

Stone, J. (2019) Public support for nationalisation increased while Jeremy Corbyn was Labour leader, poll finds, https://www.independent.co.uk/news/uk/politics/labourparty-election-corbyn-leader-polls-nationalisation-a9248511.html

Szasz, T. (1974) The Myth of Mental Illness: Foundations of a Theory of Personal Conduct, New York: Harper \& Row

Taylor, I., Walton, P. and Young, J. (1973) The New Criminology: For a social theory of deviance. London: Routledge and Kegan Paul

Townsend, P. (1962) The Last Refuge: A survey of residential institutions and homes for the aged in England and Wales. London: Routledge and Kegan Paul

Timms, N. (1964) Psychiatric Social Work in Great Britain: 1939-1962. London: Routledge and Kegan Paul

Timmins, N. (1996) The Five Giants: A biography of the welfare state. London: Fontana

Titmuss, R. (1965) A family social service. Journal of Public Health, 86, 1

Tompsett, H. (2020) Social work education: learning from the past? in T. Bamford and K. Bilton, (Eds.) Social Work: Past, present and future. Bristol: Policy Press, pp. 77-95.

Tunstill, J. and Willow, C. (2017) Professional social work and the defence of children's and their families' rights in a period of austerity: A case study. Social Work and Social Sciences Review, 19, 1, 40-65

Vanstone, M. (2004) Supervising Offenders in the Community: A History of probation theory and practice. Farnham, Ashgate

Warner, J. (2015) The Emotional Politics of Social Work and Child Protection. Bristol: Policy Press

Weinstein, J. (2011) Case Con and radical social work in the 1970s: The impatient 
revolutionaries. in M. Lavalette (Ed.) Radical Social Work Today: Social work at the crossroads. Bristol: Policy Press (p.21)

West, D. and Farrington, D. (1973) Who Becomes Delinquent? London: Heinemann

Wilmott, P. (1966) Adolescent Boys in East London. London: Routledge and Kegan Paul

Wilmott, P. and Young, M. (1960) Family and Class in a London Suburb. London: Routledge and Kegan paul

Wilson, E. (1980) Feminism and social work. in M. Brake and R. Bailey (1980) (Eds.) Radical Social Work in Practice. London: Edward Arnold (pp. 26-42)

YouGov (2017) Nationalisation vs privatisation: the public view, https://yougov.co.uk/ topics/politics/articles-reports/2017/05/19/nationalisation-vs-privatisation-public-view

Young, M. and Wilmott, P. (1957) Family and Kinship in East London. London: Routledge and Kegan Paul

Younghusband, E. (1947) Report of the Employment and Training of Social Workers. Carnegie UK Trust, Edinburgh: Constable

Younghusband, E. (1959) The Report of the Working party on Social Workers in Local Authority Health and Welfare Services. London: HMSO 